\title{
UDC 622:001
}

YAP J. M.

Library, Nazarbayev University (Nur-Sultan, Republic of Kazakhstan)

e-mail joseph.yap@nu.edu.kz, ORCID 0000-0002-7852-1047

KOZHAYEVA A.

Library, Nazarbayev University (Nur-Sultan, Republic of Kazakhstan)

e-mail altynay.kozhayeva@nu.edu.kz

\section{USE OF CHOICE REVIEWS TO BUILD THE GEOSCIENCES COLLECTION}

Objective. The Nazarbayev University School of Mining and Geosciences was established in 2016 to study and conduct research on the vast mineral reserves of the country. The school now has three bachelor's programs, two master's programs and the recently launched $\mathrm{PhD}$ program. The purpose of the study is to determine how many subjects from Choice Reviews are already part of the collection, and how many the library needs to buy to create a good geological collection. Methods. Introducing new programs, it is important to identify the academic and additional resources that will need to be offered during training. In 2018, the library acquired Choice Reviews Online to help the subject librarians create good discipline-oriented collection. Results. According to the survey, only $12.5 \%$ of the list is part of an existing print collection, and $87.5 \%$ should be added as a potential collection of mining and geology sciences. The analysis of e-book collection is as follows: $55 \%$ of the list is already part of this collection, and $45 \%$ of the library is required to be purchased when developing an e-book collection. Conclusions. The university has only just begun to develop the field of mining and geology, so there is still time to expand the library's collection of these disciplines. Subject librarians are interested in adding important titles from standardized Choice Reviews tools; as well, they should review and identify various resources that are relevant to the promotion of research to acquire them.

Keywords: mining and geosciences, collection development, earth sciences, Choice

\section{Introduction}

In 2016, the Nazarbayev University opened the School of Mining and Geosciences. Currently, it has three bachelor's programs (Geology, Petroleum Engineering, \& Mining Engineering), two master's programs (Petroleum Engineering \& Mining Engineering), and a $\mathrm{PhD}$ program which was launched in 2018. These programs are aimed at expanding research and technology in the field of mining, sustainable development, use of earth resources, etc., and encompassing mainly the Earth science of Kazakhstan the region and the world. (Suorineni, 2018). Starting a new program requires reference materials housed in the library as well as new textbooks to be used by the upcoming students. Slowly, the library is acquiring disciplineoriented resources as recommended by the faculty members.

The Subject Librarians also consult available publisher's catalog, and also do some benchmarking from our institutional partner from the USA which is the Colorado School of Mines. The Subject Librarians search the online catalog of the partner library for potential titles not owned by the library. In addition, the library purchased Choice Reviews Online to aid the subject librarian in their quest to build a standardized core collection.

Building the print collection is as important as the eBook collection. There are still users who prefer to use print materials. In a study by Foote \& Rupp-Serrano (2010), they mentioned that faculty and graduate students still prefer print books when reading the whole book as they are generally easier to use. 


\section{Methods}

The Association of College \& Research Libraries (ACRL), a division of the American Library Association (ALA) developed the Choice Reviews Online. Choice Reviews is the best origin which provides a comprehensive review of outstanding academic titles and book recommendations. For that the collection evaluation is used in this study to determine how many items from the Choice Reviews is already part of the collection. Analysis using Choice was used by subject librarians to compare whether the library is performing well in acquiring expected items as part of the collection (Stebelman, 1996). This will also show the depth of the collection based on existing standardized tools.

The Subject Librarian consulted the online database and used the filter Earth Science under Science and Technology as well as Engineering under the same category. Adding a third keyword "geoscience" gave a result of 86 hits. The results will be used to compare what is already included in the current collection. The list was extracted using create a list tool and was saved online for documentation. MS Excel was used to filter data and verifying if there are duplicate records. Using the online catalog of NU Library, the titles were searched one by one to find out which is already existing and how many print books \& eBook collection need to be added.

\section{Results and Discussion}

From the 86 results, we found out that 30 of them are duplicates. With this data, we deduct 30 from the 86 to get more reliable results. Only 12.5\% from the list is part of the existing print collection and $87.5 \%$ needs to be added as a potential collection of the School of Mining and Geosciences (Fig 1).

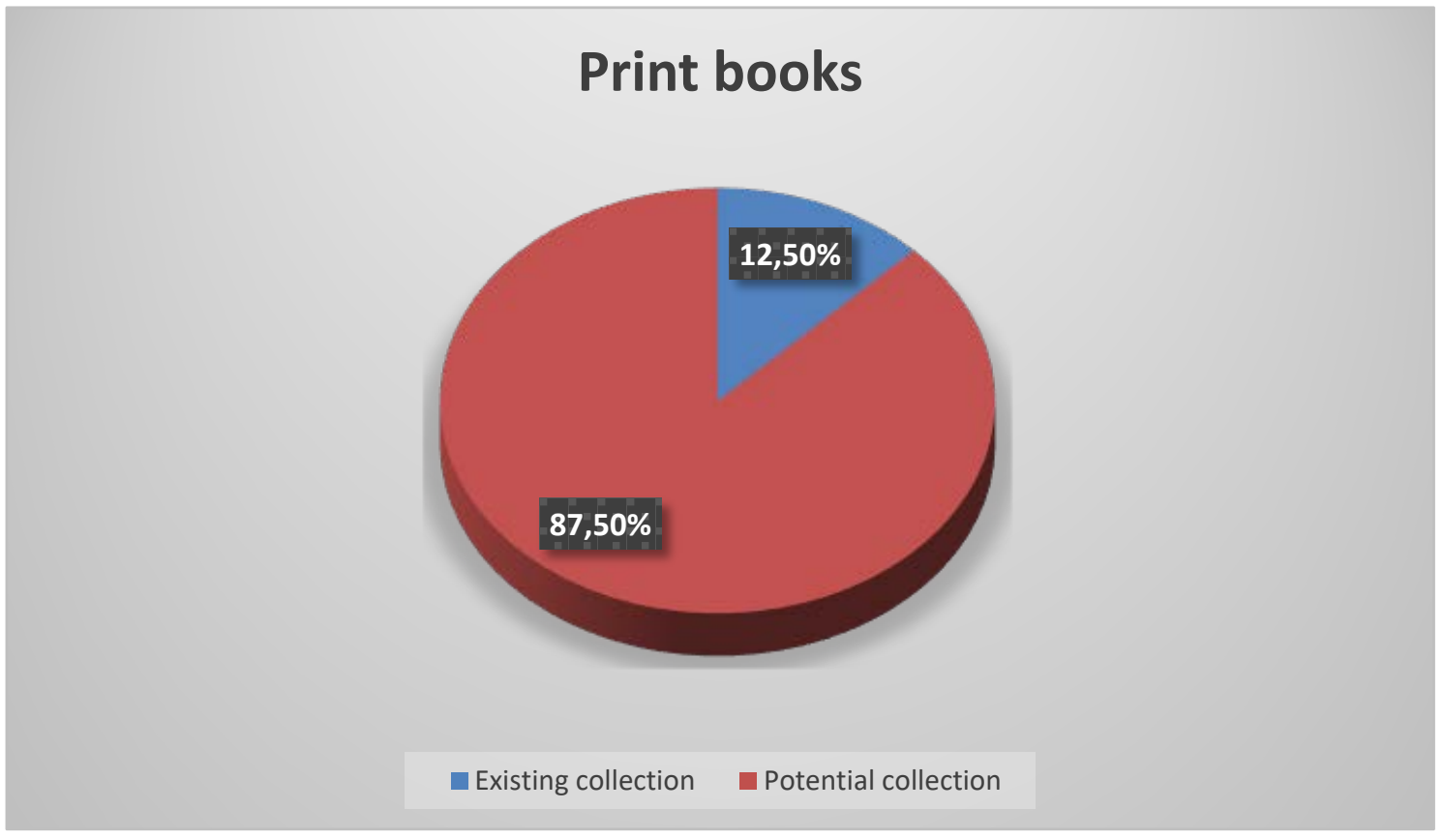

Figure 1. Comparison of print books in the NU collection vs Choice Reviews 
Some of the titles we have are Understanding Oil and Gas Shows and Seals in the Search for Hydrocarbons by John Dolson, Earthquake Engineering Handbook edited by Charles Scawthorn \& Wai-Fah Chen and Petroleum Geoscience: from Sedimentary Environments to Rock Physics edited by Knut Bjorlykke. Also, the Subject Librarian will be ordering the Earth Book: From the Beginning to the End of Our Planet, 250 Milestones in the History of the Earth Sciences by Jim Bell.

When it comes to eBook collection, 31 titles are available in the Choice Reviews Online. In that case, we can say that $55 \%$ from the list is part of the present eBook collection. It means that in developing the eBook collection, the library needs to purchase $45 \%$ (Fig 2). Results would show that we need to expand the collection to keep up with the mining and geosciences trend.

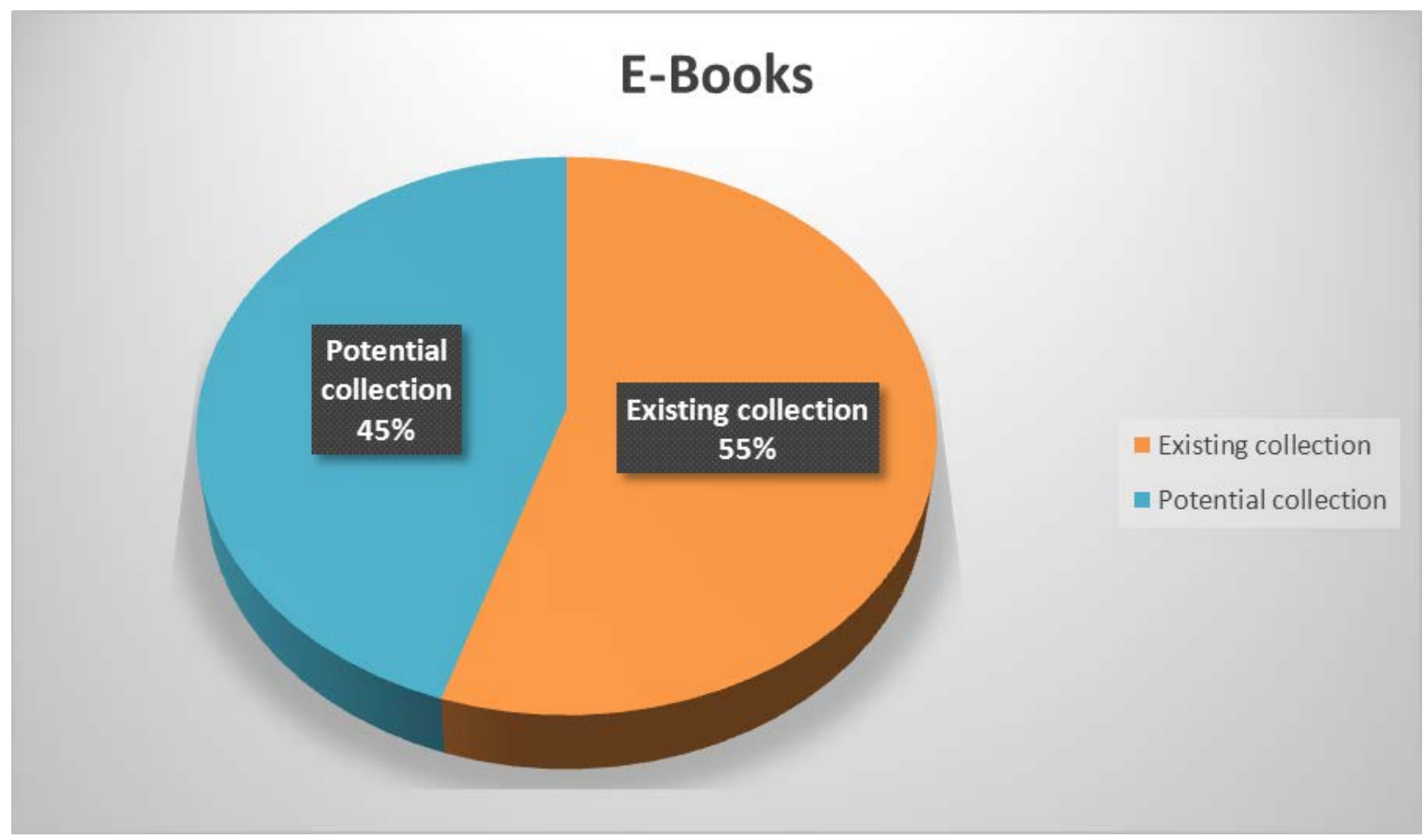

Figure 2. Comparison of eBooks in the NU collection vs Choice Reviews

While we are building the print books collection, we also need to consider expanding the eBooks collection. We can observe that we need more print books (87.5 \%) compared to eBooks which we only need $45 \%$ of it. Certainly, we cannot deny that both collections have to be developed by Subject Librarians in diverse fields of mining and geosciences.

The table below (Table 1) is an example of select titles from the Choice Reviews recommended list. The table shows the kind of format already available in our collection. However, it only presents a small amount of sample. 
Table 1. Recommended titles by Choice Reviews according to format availability in the NU collection

\begin{tabular}{|l|c|c|c|}
\hline \multicolumn{1}{|c|}{ Title: } & Print books & E-books & Combination \\
\hline 1. Four revolutions in the earth sciences & $\checkmark$ & $\checkmark$ & $\checkmark$ \\
\hline 2.Petroleum geoscience & $\checkmark$ & X & X \\
\hline 3.Geoscience Information Society & X & $\checkmark$ & X \\
\hline 4. The handbook of geoscience & $\checkmark$ & $\checkmark$ & $\checkmark$ \\
\hline 5. West's geology directory & X & X & X \\
\hline 6. Earthquake engineering handbook & $\checkmark$ & $\checkmark$ & $\checkmark$ \\
\hline
\end{tabular}

\section{Conclusions}

Since the School of Mining and Geosciences is still a developing entity of the university, there is a lot of room for collection development. Subject Librarians must be keen on adding more important titles from standardized tools such as Choice Reviews, Resources for College Libraries, Books in Print or Best Books for Academic Libraries.

A better collaboration from among the faculty members must also be established to solicit titles to be used as core text or just as part of their supplementary readings. Subject Librarians must also check and identify various resources that are corresponding to encourage research and academic programs of the faculty to recognize which books to purchase. A comprehensive collection development policy can also help improve the collection.

To further develop this study, it is recommended to use other tests such as WorldCat Collection Analysis (Benedetto \& Gilmour, 2007). It helps to better understand on how to expand the collection in necessary areas. Furthermore, we continue to evolve the collection based from faculty recommendations and student requests.

\section{REFERENCES}

Benedetto, J., \& Gilmour, B. R. (2007). Assessing collections using brief tests and WorldCat Collection Analysis. Collection Building, 26(4), 104-107. http://dx.doi.org/10.1108/01604950710831898

Foote, J. B., \& Rupp-Serrano, K. (2010). Exploring E-book usage among faculty and graduate students in the geosciences: Results of a small survey and focus group approach. Science \& Technology Libraries, 29(3), 216-234. https://doi.org/10.1080/0194262X.2010.497716

Stebelman, S. (1996). Using Choice as a collection assessment tool. Collection Building, 15(2), 4-11. https://doi.org/10.1108/01604959610113842

Suorineni, F. (2018). Welcome message from the Dean.

Retrieved from https://smg.nu.edu.kz/en/about-us-en/mission.html 
ЯП Д. М.

Бібліотека, Назарбаєв Університет (Нур-Султан, Республіка Казахстан)

e-mail joseph.yap@nu.edu.kz, ORCID 0000-0002-7852-1047

КОЖАЄВА А.

Бібліотека, Назарбаєв Університет (Нур-Султан, Республіка Казахстан)

e-mail altynay.kozhayeva@nu.edu.kz

\section{ВИКОРИСТАННЯ “CHOICE REVIEWS” ДЛЯ СТВОРЕННЯ КОЛЕКЦІї ІЗ ГЕОЛОГІЧНИХ НАУК}

Мета. У 2016 році для вивчення та проведення досліджень величезних запасів корисних копалин країни у Назарбаєв Університеті було створено школу гірничо-геологічних наук. Зараз у школі $є$ три програми підготовки бакалаврів, дві програми підготовки магістрів, а нещодавно запущено програму підготовки PhD. Мета дослідження - визначити, скільки назв із “Choice Reviews" вже є частиною колекції, а скільки бібліотеці треба придбати для створення потужної колекції літератури з геологічних наук. Методика. Із упровадженням нових програм важливо встановити академічні і довідкові джерела, які будуть потрібні під час навчання. У 2018 році бібліотека придбала “Choice Reviews” Online, щоб допомогти предметним бібліотекарям створити потужну колекцію, орієнтовану на дисципліну. Результати. За результатами дослідження лише 12,5 \% зі списку є частиною наявної друкованої колекції, а 87,5 \% потрібно додати як потенційну колекцію гірничо-геологічних наук. Аналіз колекції електронних книг такий: $55 \%$ зі списку вже є частиною цієї колекції, а 45 \% - бібліотеці потрібно придбати під час розробки колекції електронних книг. Висновки. Напрям гірничо-геологічних наук лише почав розвиватися в університеті, тому ще є час для розширення бібліотечної колекції з цих дисциплін. Предметні бібліотекарі зацікавлені в додаванні важливих назв із стандартизованих інструментів із “Choice Reviews”, а також повинні перевірити та виявити різні ресурси, які відповідають заохоченню наукових досліджень, щоб їх придбати.

Ключові слова: гірнича справа та геологічні науки; розвиток колекцій; науки про землю; Сhоiсе 